\title{
Biogeochemical Dynamics of Molybdenum in a Crater Lake: Seasonal Impact and Long-Term Removal
}

\author{
Alassane Thiam1,2, Didier Jézéquel2, Alexis Groleau², François Prévot², Filipa Lopes³, \\ Patrick Albéric ${ }^{4}$, Catherine Quiblier ${ }^{5}$, Elivira Bura-Nakic ${ }^{6}$, Irena Ciglenečki ${ }^{6}$, \\ Hassiba Lazar ${ }^{2}$, Eric Viollier ${ }^{2}$ \\ ${ }^{1}$ Université de Thiès, UFR Sciences de l'Ingénieur, Thiès, Sénégal \\ ${ }^{2}$ Laboratoire de Géochimie des Eaux, Université Paris Diderot-Institut de Physique du Globe de Paris, Paris, France \\ ${ }^{3}$ Laboratoires Génie des Procédés et Matériaux, Ecole de Chimie de Paris, Chatenay-Malabry, France \\ ${ }^{4}$ UMR611-CNRS/Université d'Orléans, Orléans, France \\ ${ }^{5}$ Muséum National d'Histoire Naturelle, Equipe "Systématique et Ecotoxicologie des Micro-Algues", Paris, France \\ ${ }^{6}$ Rudjer Boskovic Institute, Center for Marine and Environmental Research, Zagreb, Croatia \\ Email: alassane.thiam@univ-thies.sn
}

Received 22 January 2014; revised 21 February 2014; accepted 18 March 2014

Copyright (C) 2014 by authors and Scientific Research Publishing Inc.

This work is licensed under the Creative Commons Attribution International License (CC BY).

http://creativecommons.org/licenses/by/4.0/

(c) (i) Open Access

\section{Abstract}

Despite a large variety of processes that can control Mo and its potential to become an environmental tracer of euxinic environment, this element is not often studied in lakes. The aim of this paper is to identify main seasonal biogeochemical processes that involve Mo in a well constrained freshwater system (Lake Pavin water-column) in order to evaluate their respective importance. In Lake Pavin, 4 main processes have been identified: 1) the transitional process represented by Mo assimilation of by phytoplankton in the epilimnion (nitrogen biological fixation and nitrate assimilation); 2) transient process represented by dissolved Mo adsorption onto Fe and Mn metal oxides at oxic/anoxic interface (depth $50-60 \mathrm{~m}$ ); 3) Mo precipitation where apparent sulfide production rate is maximum, and from $80 \mathrm{~m}$ depths; 4) release of dissolved Mo due to Mo benthic flux or input from a deep source.

\section{Keywords}

Molybdenum; Biogeochemical Cycles; Diatoms; ICP-MS; Meromictic Lake 


\section{Introduction}

Mo is a trace element which interests both geochemists and biochemists because it plays an important role in natural biogeochemical cycles of elements such as nitrogen and sulphur cycle where they are bound to molybdenum by specific enzymes [1] [2]. Mo is also considered in marine sediment records as a proxy of anoxic paleo-environments where sulphide builds up and precipitate molybdenum [3]-[7]. In spite of molybdenum biological properties and potential reactivity in aquatic systems, there are very few works on lake ecosystem. Particularly, there is a lack of publications that compare to different biogeochemical processes [8].

The aim of this research is to identify processes that involve Mo in a well constrained freshwater system in order to evaluate their respective importance. Lake Pavin is the perfect natural laboratory to study dynamic behaviour of Mo in presence both of microalgaes, manganese and iron oxides productive layers and sulphidic layers.

\section{Biogeochemical Background}

Mo is a biologically essential trace element [9]-[15]; however, unlike many bioactive elements, variations in ocean are small [16]-[19]. Consistent with its generally conservative ocean distribution, Mo has a high salinety-normalized dissolved concentration (110 nM) [16] [17] and a modern-ocean residence time of approximately 0.8 million years [20] [21]. Rivers serve as the dominant source term for Mo to the ocean; whereas anoxic marine sedimentary systems are believed to be the primary sinks [19]-[32].

Mo is introduced into cells in molybdate ions form and operates in various enzymes where it oscillates between stages MoIV and MoVI. Unlike iron or manganese, molybdenum is not used as a final acceptor of electrons in cells [2]. Different categories of Mo enzymes were revealed by crystallography on cells of model bacteria (i.e., Escherichia coli) and can be classified on one hand in two categories linked to nitrogen cycle: nitrogenase (Enzyme multimeric complex) which is irreversibly inhibited by molecular oxygen and molybdoenzymes essentially represented by nitrate reductases [33]. On the other hand, Mo enzymes such as sulfite oxidase, formate dehydrogenase and aldehyde oxidase, were also identified [34]. They play a role in aquatic systems in the oxidation of sulphite to sulphate and dimethyl sulfo oxide to dimethyl sulphide.

At the global scale, Mo is a rare metal $(0.001 \%$ of the earth crust). In natural waters and especially in oxic conditions, Mo is present mainly under the form of molybdate ( $\mathrm{Mo}_{\mathrm{VI} 4}^{2-}$ ). Its chemical characteristics are a strong chemical inertia, as a result of covalent bonds between Mo and $\mathrm{O}$, and high solubility [31]. In lakes water column depending on oxygen conditions, processes would tend to follow a vertical sequence. Mo is important in biological processes like nitrogen fixation and nitrate assimilation under oxic conditions in lakes epilimnion. In seawater where molybdenum concentration is above $100 \mathrm{nM}$, the effect of biological uptake on molybdenum vertical distribution is not visible. In continental waters where concentrations are ten times lower, it might be worth checking for this biological signature. In oxygened waters iron and manganese hydrated oxides are also effective extractors of molybdenum [35]. Molybdates ions can be adsorbed onto oxides manganese authigenic and transported to anoxic compartment (bottom waters or sediment-water interface). This reaction allows a major molybdate redistribution throughout water column however, this observation does not explain molybdenum fixation in sediment [35]-[37]. In anoxic condition molybdenum is strongly associated with natural colloidal organic matter [38], or directly complexed by the natural organic matter [39]. Following the possible transformation of molybdate to thiomolybdates (Equations (1) to (5), molybdenum can co-precipitate with iron sulfides and organic molecules-rich sulphide participating in the capture and long term sequestration of molybdenum [27] [40] [41].

$$
\begin{gathered}
\mathrm{MoO}_{4}^{2-}+\mathrm{H}_{2} \mathrm{~S}_{(\text {aq })} \leftrightarrow \mathrm{MoO}_{3} \mathrm{~S}^{2-}+\mathrm{H}_{2} \mathrm{O}_{(\mathrm{l})} \\
\mathrm{MoO}_{3} \mathrm{~S}^{2-}+\mathrm{H}_{2} \mathrm{~S}_{(\text {aq })} \leftrightarrow \mathrm{MoO}_{2} \mathrm{~S}_{2}^{2-}+\mathrm{H}_{2} \mathrm{O}_{(1)} \\
\mathrm{MoO}_{2} \mathrm{~S}_{2}^{2-}+\mathrm{H}_{2} \mathrm{~S}_{(\text {aq })} \leftrightarrow \mathrm{MoS}_{3}^{2-}+\mathrm{H}_{2} \mathrm{O}_{(1)} \\
\mathrm{MoS}_{3}^{2}+\mathrm{H}_{2} \mathrm{~S}_{(\text {aq })} \leftrightarrow \mathrm{MoS}_{4}^{2-}+\mathrm{H}_{2} \mathrm{O}_{(\mathrm{l})} \\
\mathrm{MoO}_{4}^{2-}+4 \mathrm{H}_{2} \mathrm{~S}_{(\text {aq })} \leftrightarrow \mathrm{MoS}_{4}^{2-}+\mathrm{H}_{2} \mathrm{O}_{(1)}
\end{gathered}
$$


The equilibrium constant of reaction is:

$$
K=\left(\mathrm{MoS}_{4}^{2-}\right) /\left\{\left(\mathrm{MoO}_{4}^{2-}\right)\left(\mathrm{H}_{2} \mathrm{~S}\right)^{4}\right\}=7.4 \times 10^{19}
$$

Very recently precipitation of a previously unrecognized, probably nanoscale $\mathrm{Fe}(\mathrm{II})$-Mo(VI) sulfide mineral with predicted formula $\mathrm{Fe}_{5} \mathrm{Mo}_{3} \mathrm{~S}_{14}$ is postulated for sulfidic anoxic water column of Rogoznica Lake [42].

\section{Study Site: Lake Pavin}

Scientific literature about lake Pavin biogeochemistry is quantitatively imortant: [38] [43]-[69]. Lake Pavin is a small $\left(0.44 \mathrm{~km}^{2}\right)$, but deep $(92 \mathrm{~m})$, nearly circular lake located at an altitude of $1197 \mathrm{~m}$ in the French Massif Central $\left(45^{\circ} 30^{\prime} \mathrm{N}, 2^{\circ} 54^{\prime} \mathrm{E}\right)$. It occupies a maar crater which was formed 6900 years ago [54]. It represents the most recent period of volcanic activity in the Massif Central. Its geological setting is similar to that of other maar lakes such as Lake Nyos (Cameroon) or Laacher See (Germany). Lake Pavin is meromictic. It is characterized by the presence of permanent stratified layers: the upper layer called mixolimnion (0 to $60 \mathrm{~m}$ depth) is affected by seasonal mixing; an intermediate layer called mesolimnion (60 to $70 \mathrm{~m}$ depth); the deepest layer called monimolimnion (about 70 to $92 \mathrm{~m}$ depth). Mesolimnion and monimolimnion are anoxic and progressively enriched with depth in reduced compounds (ions $\mathrm{Fe}^{2+}, \mathrm{Mn}^{2+}, \mathrm{NH}_{4}^{+} \ldots$ ) and gazes such as $\mathrm{CO}_{2}$ and $\mathrm{CH}_{4}[54,70]$, as well as of many trace element [60] [61]. Molybdenum showed strong removal in the mesolimnion and a strong association with natural dissolved organic matter in the monimolimnion [38]. The monimolimnion is often con- sidered to have reached a geochemical steady state [58]. Dissolved molybdenum in the water column comes from 16 surface streams (Figure 1) and sublacustrine inputs.

Subsurface inputs at about $45 \mathrm{~m}$ and $85 \mathrm{~m}$ are discussed in [60] [61] and [71]. Basically, the $45 \mathrm{~m}$ depth input has a composition close to surface running waters with an average flow rate close to the average visible surface input [71]. The $85 \mathrm{~m}$ depth input has a composition influenced by mineral springs emerging in the area. The best surrogate is Fontaine Goyon a mineral spring located $1.5 \mathrm{~km}$ from Lake Pavin crater. Regular visual observations indicate that the water level of the lake has been stable, within an uncertainty of $50 \mathrm{~cm}$, for at least several decades. Dissolved molybdenum in rain is $<1 \mathrm{nM}$ [61].

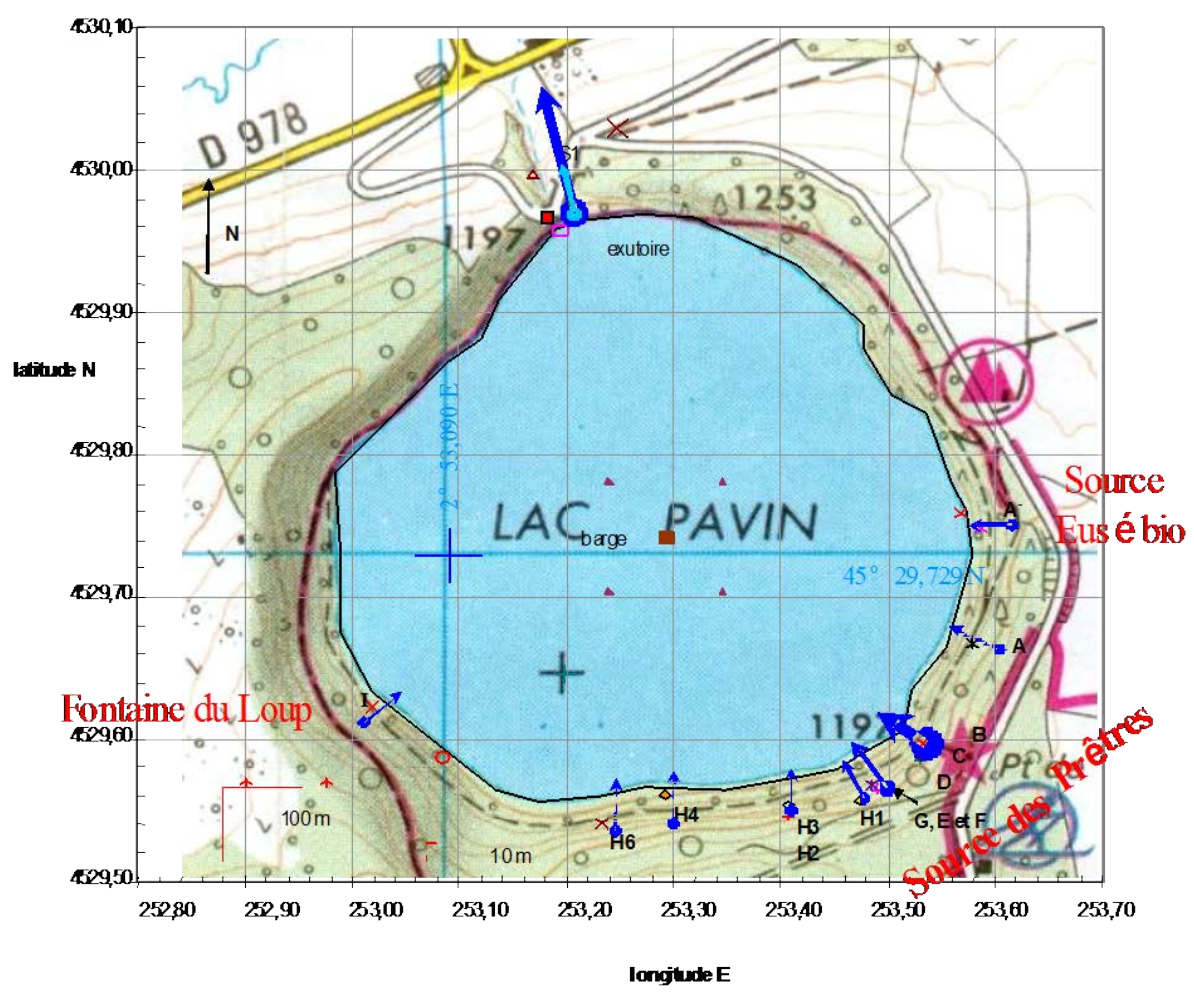

Figure 1. Tributaries location (France) and Lake Pavin. 


\section{Methods}

Water column and rivers sampled were collected and analyzed during METANOX multidisciplinary project (Biodiversity and Metabolism in Anoxic Aquatic Systems). During this project, 17 monthly campaigns from May 2006 to August 2007 were carried out.

\subsection{Water Column Monitoring}

During first campaigns, samples were collected from a platform $\left(45^{\circ} 29.740 \mathrm{~N}, 2^{\circ} 53.280 \mathrm{E}\right)$ at depth by a $50 \mathrm{ml}$ syringe sampler. For other campaigns we used a syringe of 1 liter. This latter syringe sampler is a lab-made prototype designed for an accurate sampling depth and to avoid gas bubble formation during retrieval. Small tributaries are sampled for various analyses directly with a $50 \mathrm{~mL}$ Polypropylene syringe. Filtration is done with a Sartorius Luer membrane support rinsed with the sample immediately after retrieving the syringes. Filtered samples for trace element analyses (i.e., molybdenum) are acidified with Merck Suprapur nitric acid. In addition tests of chemical entity sizing were done using ultrafiltration in the monimolimnion [38], for operational details. Separative membrane allowed the following cut off sizes: $1 \mathrm{kDa}, 5 \mathrm{kDa}, 10 \mathrm{kDa}, 0.45 \mu \mathrm{m}$.

\subsection{Settling Particles}

Settling particles in Lake Pavin were collected at 4 strategic depths according to physical and biogeochemical stratification: $23 \mathrm{~m}$ (below biological production), $58 \mathrm{~m}$ (above the mesolimnion), $70 \mathrm{~m}$ (below the mesolimnion), and $88 \mathrm{~m}$ (above sediment). For June, July, August and September 2006 campaigns, 4 lab-made sediment traps deployed on individual lines [61] were maintained in position by a $15 \mathrm{~kg}$ weight at the lake bottom and a buoy at the lake surface. Concerning the remaining campaigns 4 Uwitec ${ }^{\circledR}$ sediment traps have been used on a single vertical line attached to a platform in the center of the lake. Two cylinders per depth were available. Sodium azide was used as a poison to prevent particles degradation by microorganism. Immediately after sampling, settled samples are filtered under nitrogen atmosphere on GFF membrane with average size of $0.6 \mathrm{~mm}$.

\subsection{Diatoms Culture}

In order to estimate independently the potential impact of molybdenum uptake by algae on the lake water column, Diatoms Aulacoseira italica (phytoplankton dominant species, 80\% of microalgae species in FebruaryMarch 2007) was grown in the lab from a known quantity of molybdenum. Diatoms originated from LMGE collection at University of Clermont-Ferrand. $100 \mathrm{nM}$ of molybdenum were added in Synura growth medium [72] (Table 1). The culture was carried out in one control and 3 replicates. Control (250 ml) is equivalent of synura medium while each replicats consists of $250 \mathrm{ml}$ synura medium and $50 \mathrm{ml}$ of homogenized diatoms strains. The culture has been carried out on a regular workbench at $25^{\circ} \mathrm{C}$ with alternating outdoor daylight and outdoor darkness. Samples were taken daily to measure absorbance at $670 \mathrm{~nm}$ in order to estimate algal biomass growth.

All visible spectroscopic measurements were carried out on an ICP-MS by using an internal standard ${ }^{115}$ In $(1$ $\mu \mathrm{g} / \mathrm{L})$ to correct matrix effects and derivatives.

Analytical quality was made by a SLR4, certified standard. Mo was determined in filtered and acidified samples by ICP-MS.

Table 1. Growth media for diatoms culture.

\begin{tabular}{|c|c|c|c|}
\hline \multicolumn{4}{|c|}{ Synura Media (Mignot-Brugerolle, 1982) in $1 \mathrm{~L}$} \\
\hline Chemical formula & m (g) & $\mathrm{M}\left(\mathrm{g} \cdot \mathrm{mol}^{-1}\right)$ & $\mathrm{C}\left(\mathrm{mol} \cdot \mathrm{L}^{-1}\right)$ \\
\hline $\mathrm{CaCl}_{2} 2 \mathrm{H}_{2} \mathrm{O}$ & 0.03676 & 147 & $2.50 \mathrm{E}-04$ \\
\hline $\mathrm{MgSO}_{4} 7 \mathrm{H}_{2} \mathrm{O}$ & 0.03697 & 246 & $1.50 \mathrm{E}-04$ \\
\hline $\mathrm{NaHCO}_{3}$ & 0.0126 & 84 & $1.50 \mathrm{E}-04$ \\
\hline $\mathrm{K}_{2} \mathrm{HPO}_{4}$ & 0.00403 & 174.18 & $2.31 \mathrm{E}-05$ \\
\hline $\mathrm{NaNO}_{3}$ & 0.8501 & 85 & $1.00 \mathrm{E}-02$ \\
\hline $\mathrm{Na}_{2} \mathrm{SIO}_{3} 5 \mathrm{H}_{2} \mathrm{O}$ & 0.02842 & 212 & $1.34 \mathrm{E}-04$ \\
\hline
\end{tabular}

$+5 \mathrm{ml}$ of oligo-nutrients solution, $1 \mathrm{ml}$ of Thiamine $\mathrm{HCl}, 5 \mathrm{ml}$ of biotine, $0.5 \mathrm{ml}$ of B12 vitamin, pH adjusted at $7.5 \pm 0.2 \mathrm{mith}$ Suprapur HCl. 


\subsection{Laboratory and Field Analyses}

\subsubsection{Auxiliary Parameters}

In order to locate physico-chemical gradients, vertical CTD profiles are done with a Seacat Seabird CTD profiler (pressure/depth, temperature, conductivity, dissolved oxygen, $\mathrm{pH}$ ). It has resulted in situ vertical profiles of main physical and chemical parameters over the entire water column of the lake.

\subsubsection{Iron and Manganese}

Dissolved iron (II) is measured by colorimetry at $565 \mathrm{~nm}$ by the ferrozine method [61]. Dissolved manganese concentration is determined by ICP-AES (Optima 3000, Perkin Elmer).

\subsubsection{Nitrate, Sulphate and Total Sulphide}

Volatile and oxidizable sulfide is trapped after filtration at the time of sampling by precipitation in the form of insoluble zinc sulfide. These solid/colloids are maintained in suspension with the addition of gelatin. Sulfide is measured colorimetrically at $665 \mathrm{~nm}$. Nitrate and sulfate are determined with ion chromatography after addition of cadmium acetate to prevent sulfide oxidation to sulfate.

\subsubsection{Molybdenum}

Samples stored in the dark at $5^{\circ} \mathrm{C}$ in Polypropylen tubes were analyzed by ICP-MS (X7 series Thermo Scientific). ICP-MS analyses were calibrated with an external standardization. Internal standard technique using ${ }^{115} \mathrm{In}$ at $1 \mu \mathrm{g} / \mathrm{L}$ was used in order to correct matrix and drift effect. Particles samples obtained from sediment traps were analysed at CRPG (Nancy, France) for C, H, N and S. For molybdenum, only two samples were analysed at CRPG (58 $\mathrm{m}$ and $70 \mathrm{~m}$ ) by ICP-MS after complete sample dissolution.

\section{Results}

\subsection{Mixolimnion Stratification}

Figure 2 shows vertical profiles of temperature in Lake Pavin. During 2006, surface temperature increases until July before decreasing by nearly $5^{\circ} \mathrm{C}$ in August. At this time the metalimnion moves down allowing surface water to mix partly with hypolimnion waters. Cooling down goes on until autumn when the lake surface starts to freeze. From melting ice in March 2007 to June 2007, temperature goes up.

Figure 3 presents dissolved oxygen concentrations evolution in Lake Pavin. Residual peak of oxygen is almost always visible at metalimnion depth (excluding December when no significant peak is observed). During high photosynthesis activity (supersaturation is often observed in the epilimnion), oxygen accumulates in the less dynamic zone (metalimnion) where exchange with the atmosphere or with the hypolimnion is limited. From May to September the oxycline rises up in the water column from 58 to $52 \mathrm{~m}$. When the oxycline rises upward in the water column the chemocline (shown through the iron profile in Figure 4 does not undergo such vertical shift (nearly 10 meters).

\subsection{Redox Biogeochemical Cycles}

Nitrate, spite of input surface concentration $>20 \mu \mathrm{mol} \cdot \mathrm{L}^{-1}$, shows almost constantly concentrations $<5 \mu \mathrm{mol} \cdot \mathrm{L}^{-1}$ in the epilimnion (Figure 5) mostly due to uptake by growing phytoplankton. Nitrification of large concentrations of ammonium $\left(>1 \mathrm{mmol} \cdot \mathrm{L}^{-1}\right)$ can explain the presence of a nearly constant nitrate peak above the mesolimnion.

Iron (II) (Figure 4) and manganese (Figure 6) in very low concentration in the mixolimnion show significant accumulations in the meso-monimolimnion layers; especially dissolved iron for which concentrations reach 1 $\mathrm{mmol} \cdot \mathrm{L}^{-1}$. Consequently, metal oxides formed in the oxycline zone are likely to be present [62] and might follow the oxycline when rising up. Sulfate reduction within the mesolimnion causes the production of sulfide (Figure 7), sulfide oxidation by-products $(\mathrm{S}(0)$ ) and colloidal iron sulfide [68] [69]. Sulfide results are very close to those published by [58].

\subsection{Molybdenum}

Roughly, dissolved molybdenum in tributaries ranges from 5 to $15 \mathrm{nmol} \cdot \mathrm{L}^{-1}$ (Figure 8(a)) depending on tributary 

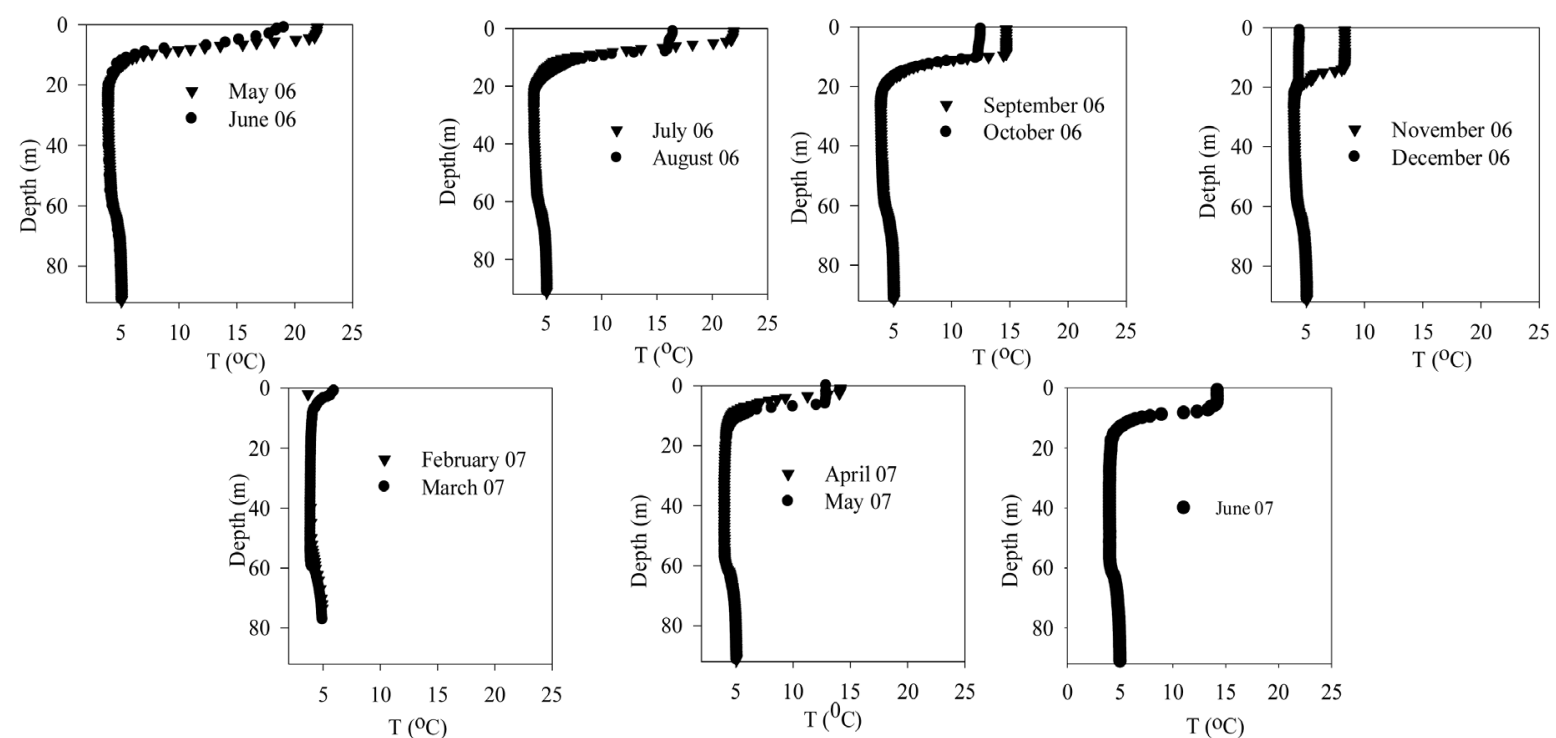

Figure 2. Lake pavin-Temperature data.
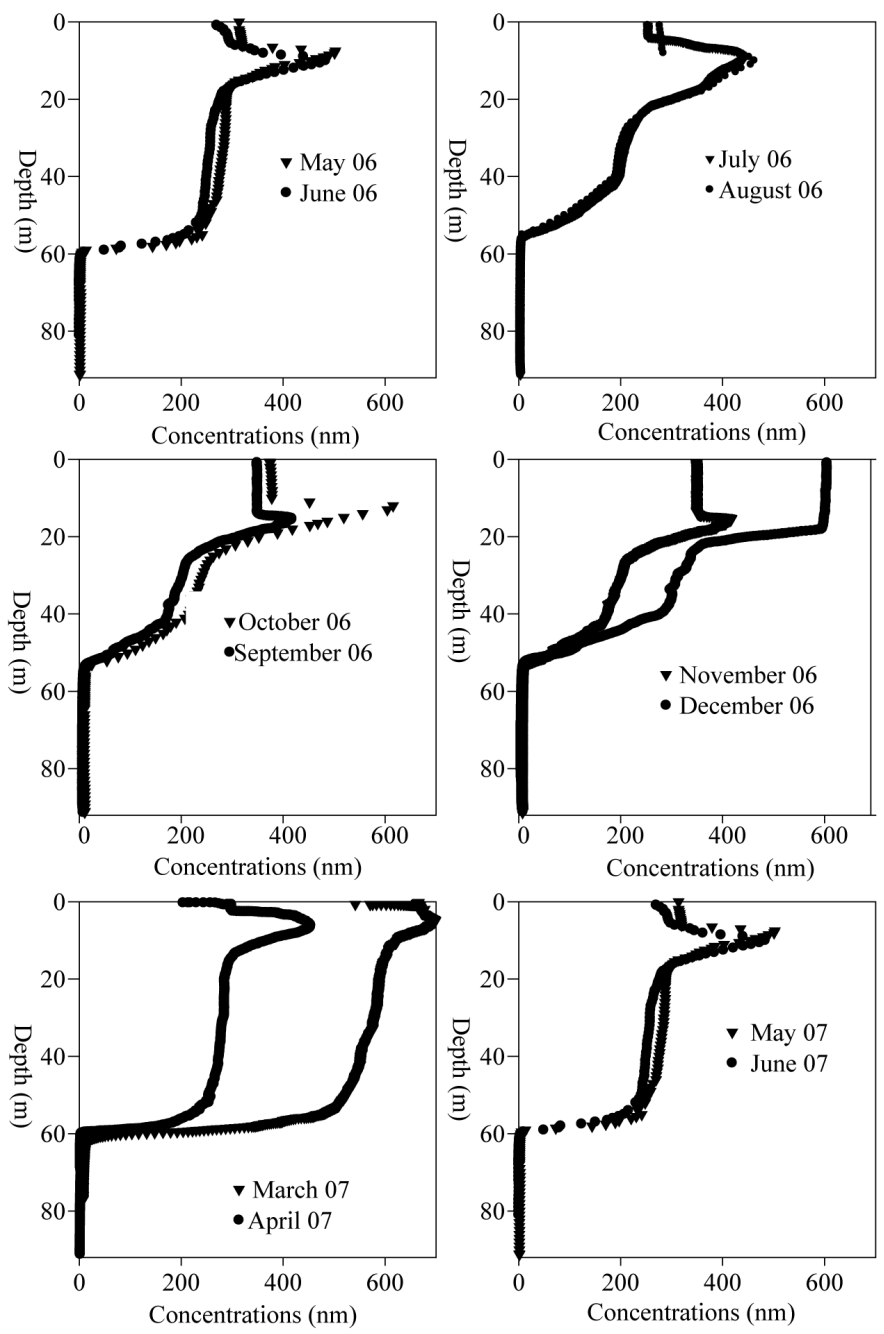

Figure 3. Lake pavin-Oxygen data. 


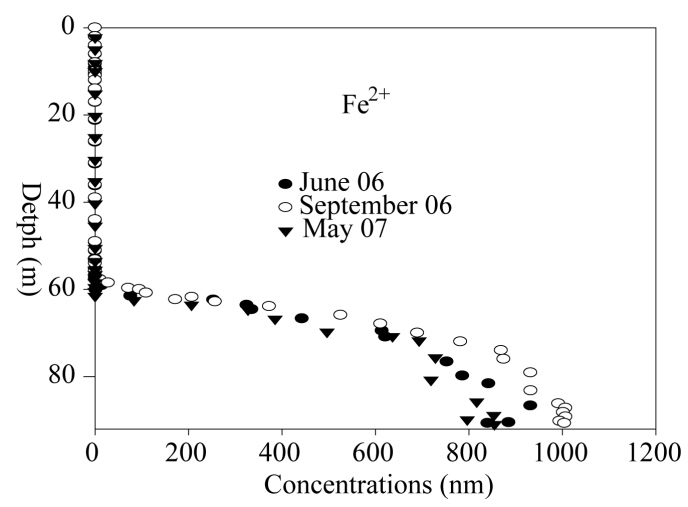

Figure 4. Iron (II) in deep layers of Lake Pavin.
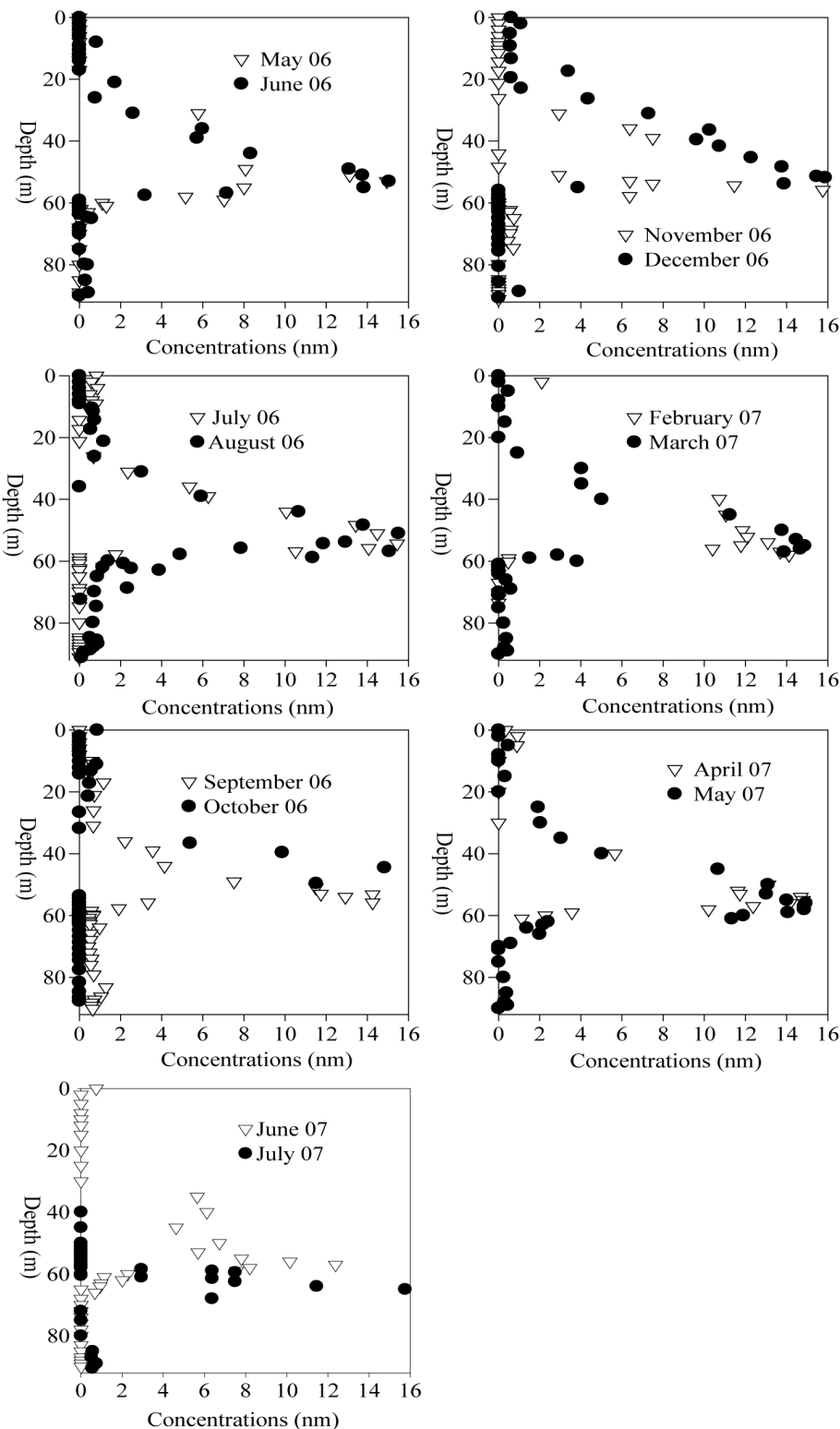

Figure 5. Nitrate seasonal dynamics in Lake Pavin. 


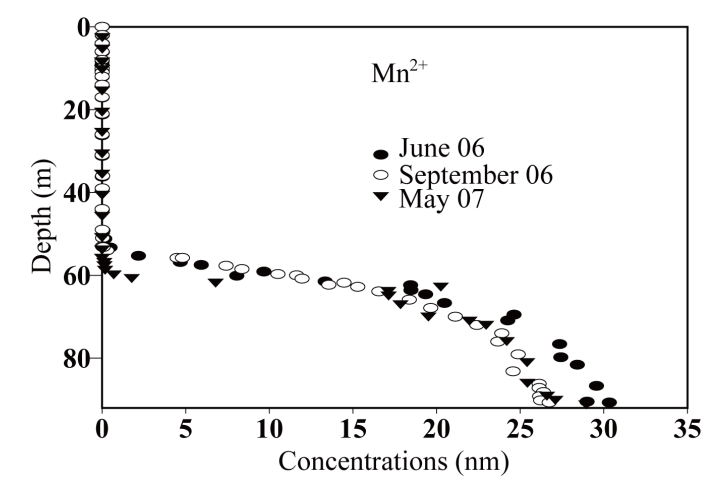

Figure 6. Manganese in deep layers of Lake Pavin.

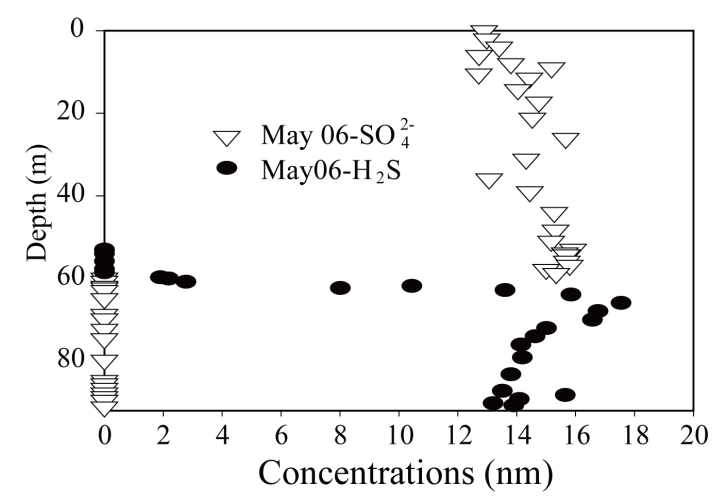

Figure 7. Sulphate and sulphide in Lake Pavin.

or period of the year. From measured flow rates (Figure 8(b)), one can calculate a weighted average concentration entering the lake annually of $11 \mathrm{nmol} \cdot \mathrm{L}^{-1}$. In deep layers, ultrafiltration results (Figure 9(a)) point out the presence of molybdenum in rather large molecules $>10 \mathrm{kDa}$. Organic molecules (Figure 9(b)) are the best candidates to carry molybdenum in the monimolimnion through binary or ternary association however association with iron sulfide species cannot be ruled out [42].

From May 2006 to October 2006, slight dissolved molybdenum depletion is observable in the epilimnion (Figure 10). This feature disappears in autumn when the mixolimnion becomes homogeneous. More permanent is the removal feature observable in the oxycline zone (about $50 \mathrm{~m}$ depth). Also permanent but more consequent is the removal feature that is observed within the mesolimnion and already described in [61]. The maximum removal leading to concentrations $<5 \mathrm{nmol} \cdot \mathrm{L}^{-1}$ occurs in the zone of maximum sulfide production (Figure 10).

\subsection{CHNS}

Table 2 presents the results obtained on settling particles from sediments traps. Their average carbon content is close to $12 \%$ (Table 2). The highest value (19\%) is found in the hypolimnion whereas the lowest value is found in the monimolimion (7.5\%) corresponding likely to partly degraded material. This can also be observed in nitrogen content which varies from 2 in the mixolimnion to $1 \%$ in the monimolimnion. Degradation by-products are likely to be the source of organic macromolecules detected in the monimolimnion.

Mass fluxes show higher values during March and April. This period corresponds to the bloom of diatoms (Table 3). In this period, analyses show that Mo concentrations are varying between 9.304 and 13.53 ppm

\subsection{Diatoms Culture}

Absorbance measurements for control and replicates show (Figure 11(a)) a lag phase until day 6, followed by a nearly exponential growth until a stationar activity which is recorded in the last day of the experiment. Corres- 


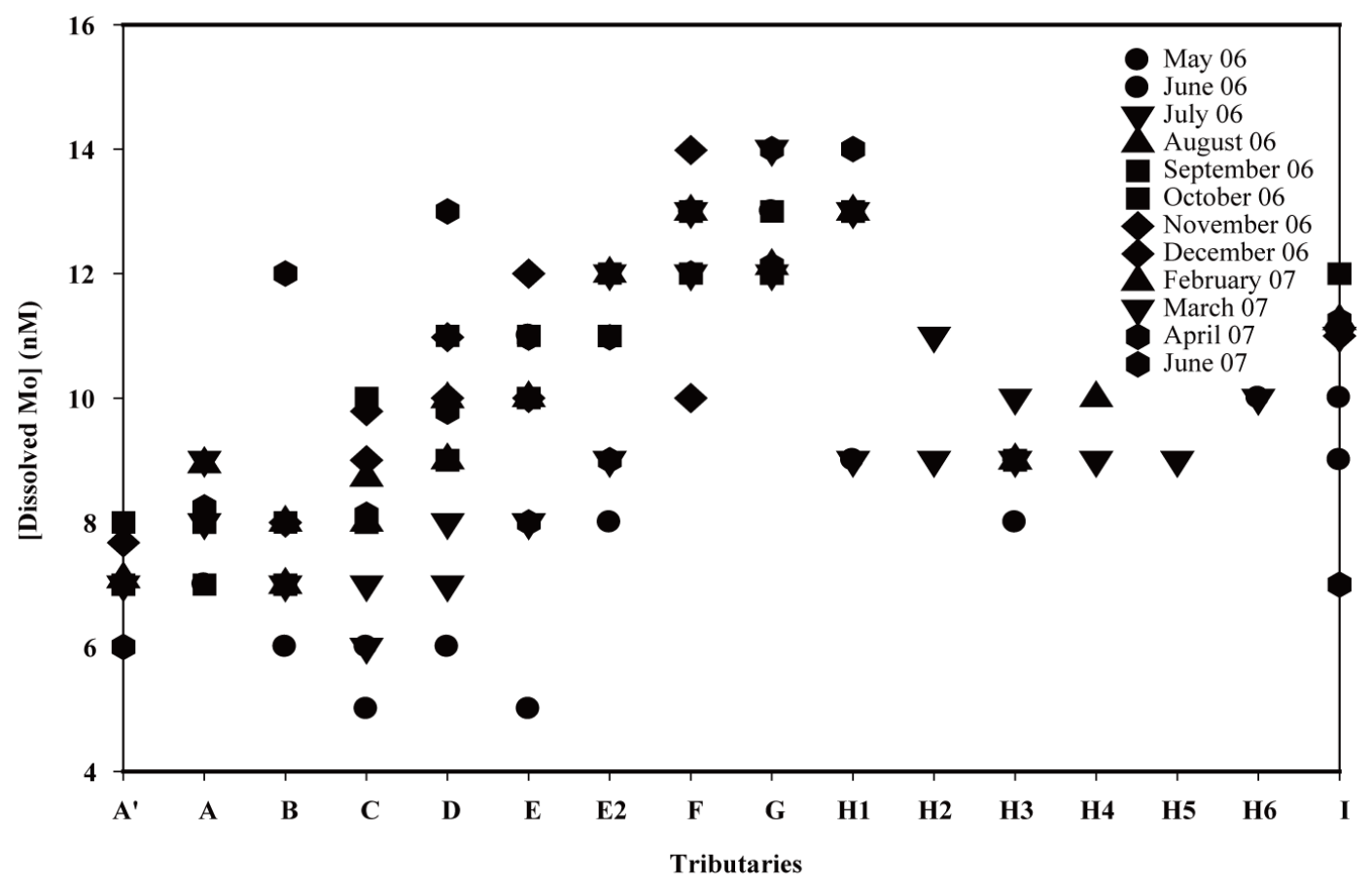

(a)

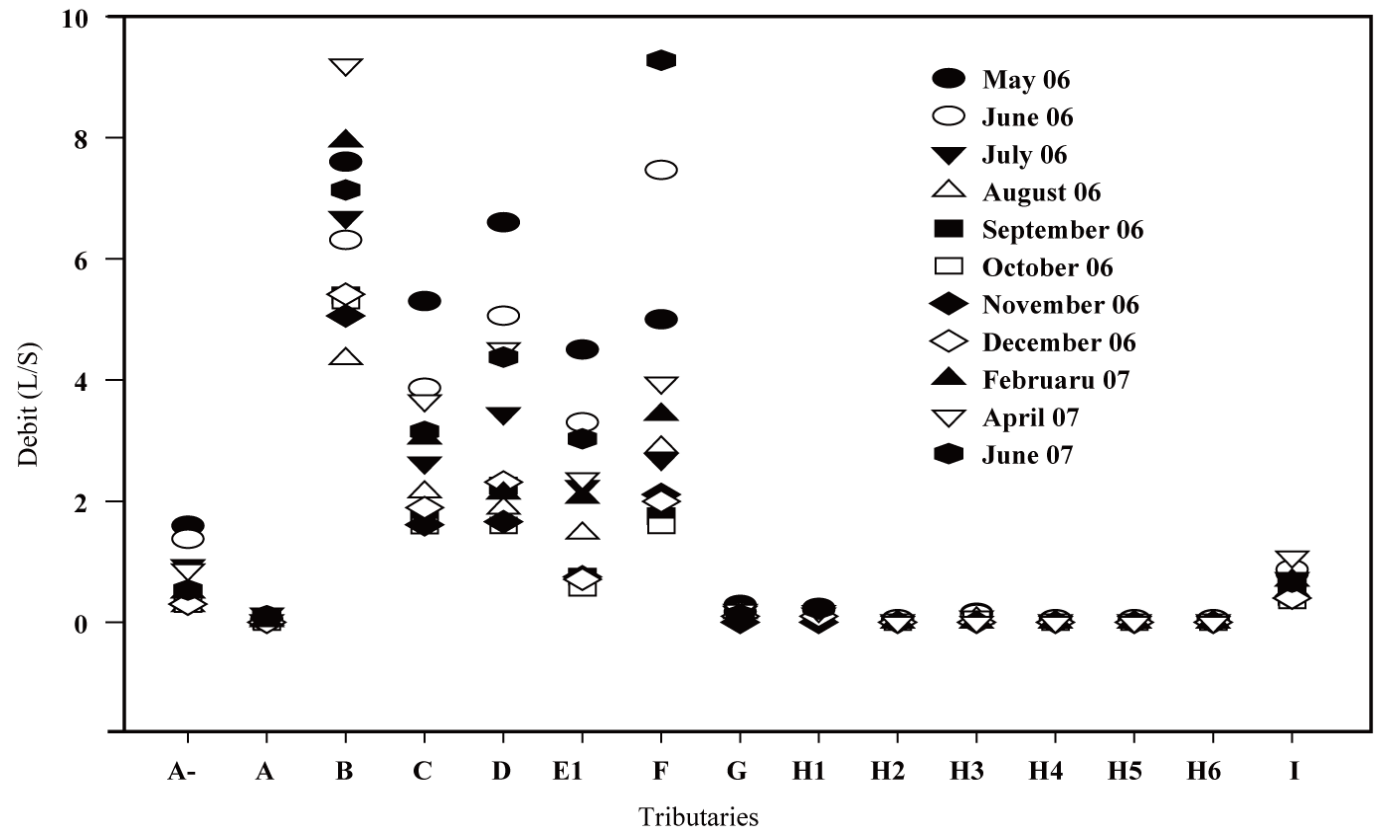

(b)

Figure 8. (a) Molybdenum seasonal dynamics in tributaries; (b) Mo flow rate dynamics of tributaries.

ponding molybdenum uptake shows (Figure 11(b)) the same lag period but followed by a constant removal rate until reaching the stationary phase. Direct (filament) cell counting with an optic microscope from an aliquot is rather difficult and lead to less smoothed data (Figure 11(c)); cell $\cdot \mathrm{L}^{-1}$ ). If one presume that molybdenum uptake in the experiment is related to assimilation alone and not adsorption at cell surface (which remains to be proven), it is possible to calculate a first order estimate of molybdenum growth requirement (in this experiment) per cell unit. Such estimation leads to $5 \times 10^{-6} \mathrm{nmol} \cdot \mathrm{cell}^{-1}$. 


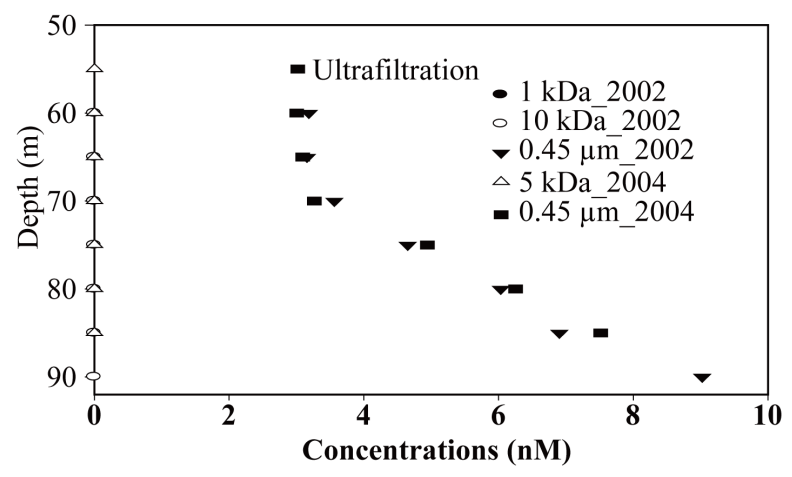

(a)

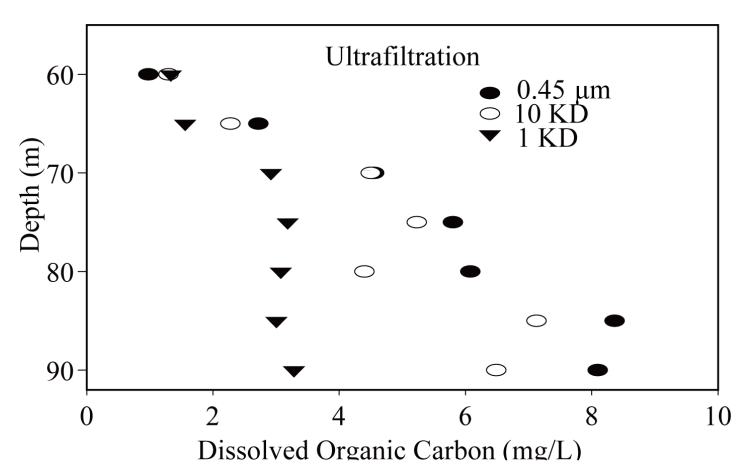

(b)

Figure 9. (a) Molybdenum size; (b) DOC size.
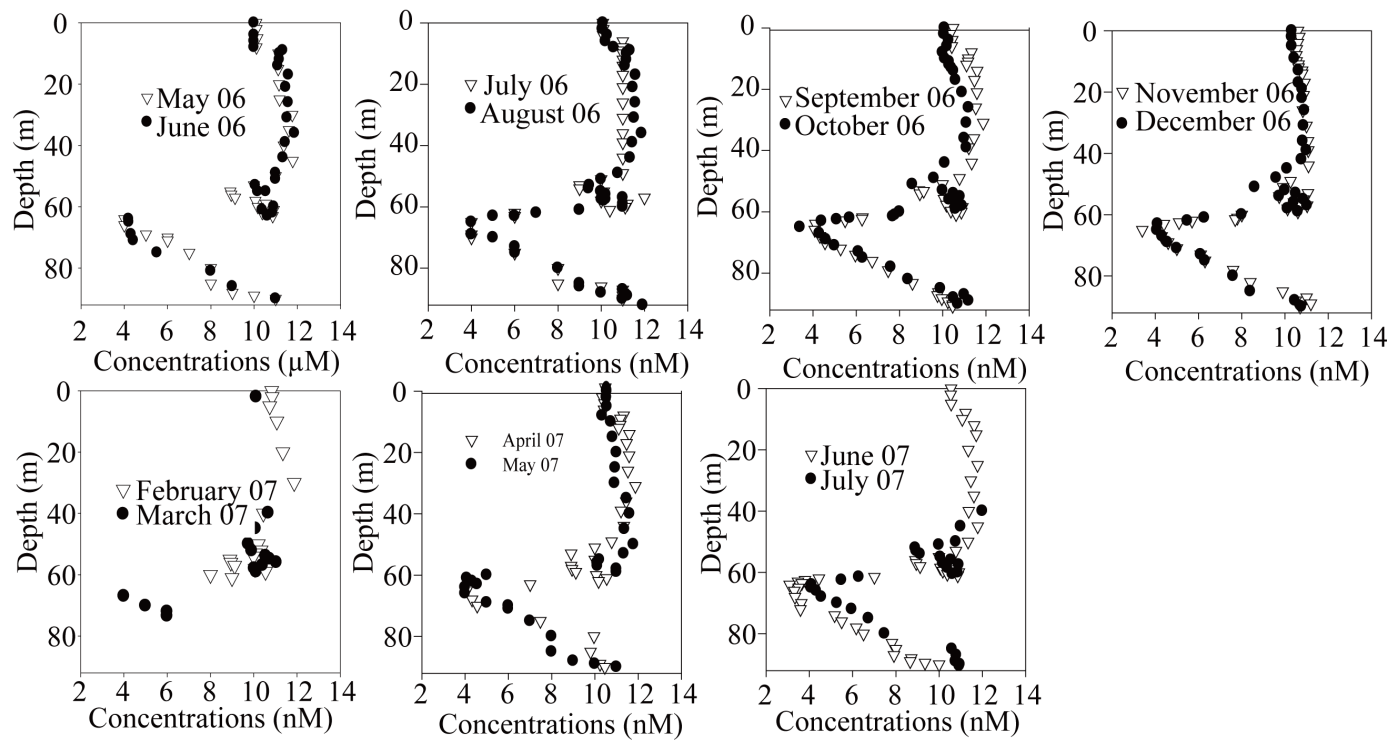

Figure 10. Dissolved molybdenum seasonal dynamics.

Table 2. Mass \% of C, H, N and S measured on settling particles.

\begin{tabular}{|c|c|c|c|c|}
\hline \multicolumn{5}{|c|}{ Mass \% } \\
\hline Samples Identification & $\mathrm{N}$ & $\mathrm{C}$ & $\mathrm{H}$ & $\mathrm{S}$ \\
\hline February-2007-(with $\left.\mathrm{NaN}_{3}\right)(23 \mathrm{~m})$ & 1.41 & 10.46 & 2.38 & 0.24 \\
\hline March-2007-(with $\left.\mathrm{NaN}_{3}\right)(23 \mathrm{~m})$ & 1.81 & 14.43 & 2.91 & 0.17 \\
\hline April-2007-(with $\left.\mathrm{NaN}_{3}\right)(23 \mathrm{~m})$ & 2.10 & 19.25 & 2.91 & $\nLeftarrow$ \\
\hline May-June-2007-(with $\mathrm{NaN}_{3}$ ) (23 m) & 1.69 & 12.76 & 2.80 & 0.11 \\
\hline February-2007-(with $\left.\mathrm{NaN}_{3}\right)(58 \mathrm{~m})$ & 1.33 & 9.19 & 2.47 & 0.12 \\
\hline March 2007-(with $\mathrm{NaN}_{3}$ ) (58 m) & 1.43 & 10.78 & 2.79 & 0.11 \\
\hline February-07-(with $\mathrm{NaN}_{3}$ ) (70 m) & 1.70 & 14.69 & 2.73 & 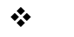 \\
\hline March-2007-(with $\mathrm{NaN}_{3}$ ) (70 m) & 1.13 & 7.98 & 2.29 & 0.17 \\
\hline February-2007-(with $\mathrm{NaN}_{3}$ ) (88 m & 1.38 & 9.76 & 2.74 & 0.19 \\
\hline March-2007-(with $\mathrm{NaN}_{3}$ ) (88 m) & 1.06 & 7.53 & 2.1 & 0.16 \\
\hline
\end{tabular}

* Any chemical analyses.

\section{Discussions}

\subsection{Evidence of Phytoplankton Growth Impact on Dissolved Mo Distribution} in the Mixolimnion

Nitrate reductase is an enzyme used both in nitrate assimilation in cells and also during intermediate steps of 
Table 3. Mass fluxes obtained by traps sediment.

\begin{tabular}{|c|c|c|c|c|c|c|c|c|}
\hline \multicolumn{9}{|c|}{ Flux (g/m²/day) } \\
\hline & \multicolumn{2}{|c|}{$23 \mathrm{~mm}$} & \multicolumn{2}{|c|}{$58 \mathrm{~mm}$} & \multicolumn{2}{|c|}{$70 \mathrm{~mm}$} & \multicolumn{2}{|c|}{$88 \mathrm{~mm}$} \\
\hline Dates of camnaigns & without & with $\mathrm{NaN}_{3}$ & without $\mathrm{NaN}_{2}$ & with $\mathrm{NaN}_{3}$ & without $\mathrm{NaN}_{2}$ & with $\mathrm{NaN}_{3}$ & without $\mathrm{NaN}_{2}$ & with \\
\hline $\begin{array}{c}\text { Dates of campaigns } \\
\text { June-06 }\end{array}$ & $\mathrm{NaN}_{3}$ & ${ }^{*}$ & 0.13 & $*$ & 0.02 & * & 0.46 & $\mathrm{NaN}_{3}$ \\
\hline July-06 & 0.16 & $*$ & 0.81 & $*$ & 0.73 & $*$ & $\begin{array}{l}0.40 \\
1.53\end{array}$ & $*$ \\
\hline August-06 & 0.78 & $*$ & $\begin{array}{l}0.01 \\
1.99\end{array}$ & $*$ & 1.12 & $*$ & 0.34 & $*$ \\
\hline September-06 & 0.13 & * & 0.09 & * & 0.12 & * & 0.09 & $\begin{array}{l}* \\
*\end{array}$ \\
\hline October-06 & 0.04 & 0.2 & 0.08 & 0.26 & 0.22 & 0.24 & 0.28 & $*$ \\
\hline November-06 & $\begin{array}{l}0.09 \\
018\end{array}$ & 0.21 & 0.24 & 0.22 & 0.3 & 0.35 & 0.28 & 0.3 \\
\hline February-07 & 0.18 & 0.19 & 0.19 & 0.25 & 0.11 & 0.1 & 0.44 & 0.41 \\
\hline March-07 & 0.17 & 2.05 & 0.15 & 4.01 & 1.26 & 1.11 & 0.67 & 0.65 \\
\hline April-07 & 3 & 3.3 & 5.94 & 2.53 & 4.17 & 2.32 & 1.34 & 0.8 \\
\hline May-07 & 3.49 & 0.38 & 2.71 & 0.312 & 0.59 & 0.59 & $\begin{array}{l}1.34 \\
0.67\end{array}$ & 1.83 \\
\hline IVIay-0 & 0.38 & & & & & & & 0.60 \\
\hline
\end{tabular}

* means traps with single pipe.

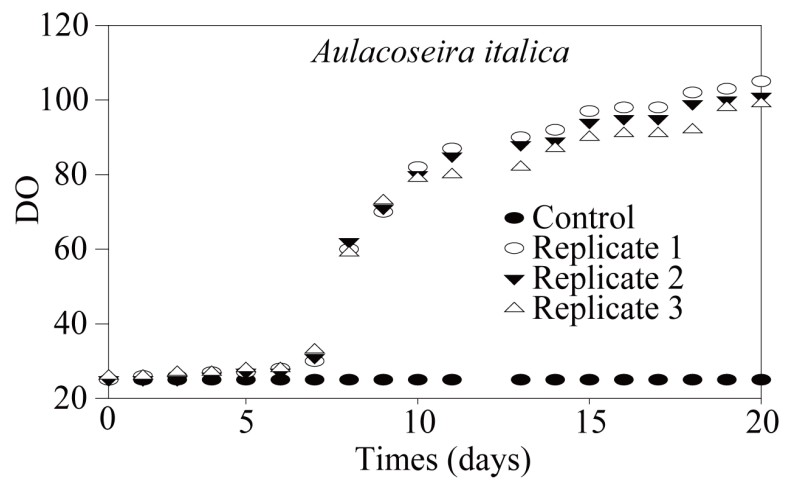

(a)

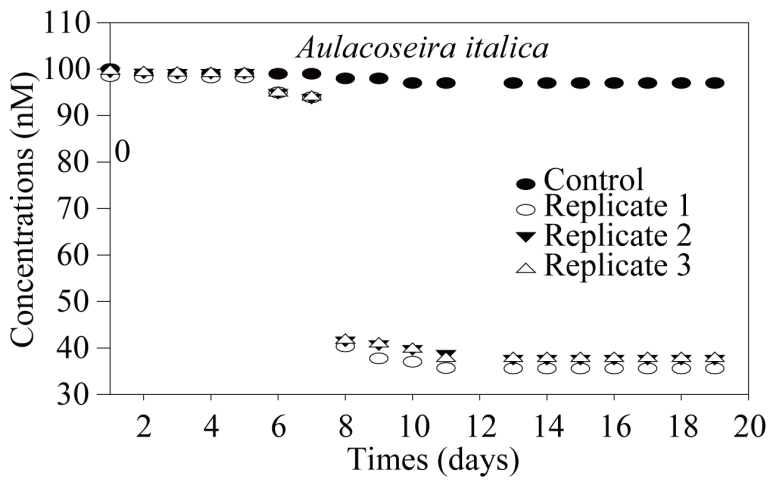

(b)

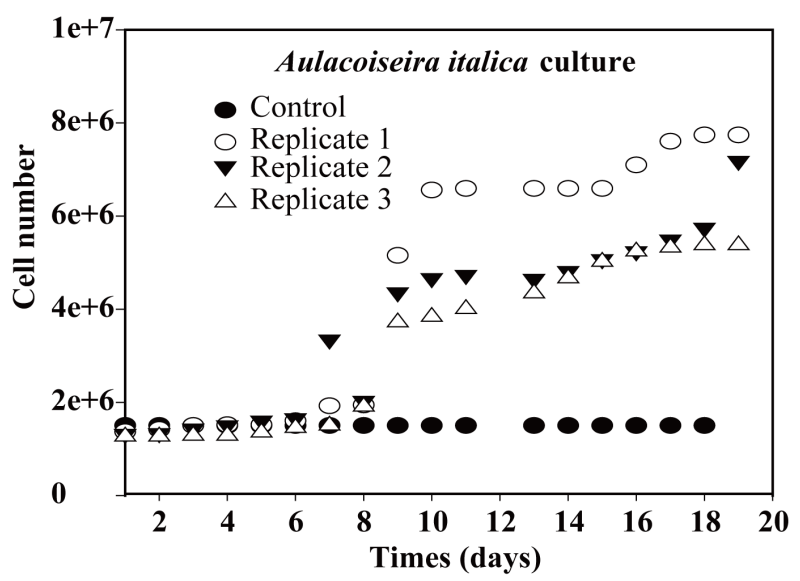

(c)

Figure 11. (a) Aulacoseira italica culture: absorbance (DO); (b) Aulacoseira italica culture: Molybdenum; (c) Aulacoseira italica culture: cell number equivalent.

nitrification. Since both processes are obviously active in Lake Pavin, as well as denitrification as suggested by [70], it would be straightforward to attribute the epilimnion slight depletion in spring and summer to microbiological activity. On one hand, one cannot exclude, tributaries seasonal variations to explain the observation since the average input of $11 \mathrm{nmol} \cdot \mathrm{L}^{-1}$ matches closely the winter value of the mixolimnion. On the other hand, during high productivity period for diatoms (late February to late March), it is usual to find more than $10^{7} \mathrm{cell} \cdot \mathrm{L}^{-1}$. This would correspond to a growth uptake of $50 \mathrm{nmol} \cdot \mathrm{L}^{-1}$ in the right order of magnitude to influence epilimnion 
molybdenum concentration. Though the growth dynamics is not completely solved to conclude definitely and the direct transfer from lab pure culture to the field can be strongly biased, this simple approach supports the idea of a visible molybdenum uptake par phytoplankton.

\subsection{Oxycline Seasonal Change and Molybdenum Adsorption/Release onto/from Metal Oxides}

Along with the rise of the oxycline, molybdenum depletion moves also upward in the mixolimnion (i.e., decrease starts shallower), supporting the idea of a removal by adsorption onto authigenic metal oxides. However, the depletion maximum corresponds also roughly to the layers of the "river type" sublacustrine input. The intake of slightly less concentrated water would create the depletion of few $\mathrm{nmol} \cdot \mathrm{L}^{-1}$. The use of a dynamic reactive transport model of the lake would probably solve this assumption.

\subsection{Long Term Control by Iron and Sulfur Species}

Removal feature in the mesolimnion has already been observed by [60] [61]. However, the seasonal study allows demonstrating the permanence of this process. Viollier [61] have already published particulate Mo data that demonstrate the strong formation of Mo-bearing particles in the mesolimnion: 2 to $4 \mathrm{nmol} \cdot \mathrm{L}^{-1}$ were measured. This concentration is very significant in comparison to dissolved molybdenum in the monimolimnion (4 to 10 $\mathrm{nmol} \cdot \mathrm{L}^{-1}$ ). Framboïdal pyrite was also discovered more than a decade ago forming in Lake Pavin [61] while very recent work revealed the presence of $S^{0}$ in micromolar levels and the presence of colloidal FeS which comprises around $70 \%$ of total sulfide measured in nonfiltered samples [68] [69].

Thiomolybdates are postulated as key species in sulfidic aquatic systems. However, they are not yet measured in such environments. If thiomolybdates formation is the first step of molybdenum scavenging, these species must be stable in such solution.

Thiomolybdates equilibrium concentrations from the first molybdate sulfuration to monothiomolybdate $(0-1)$ until the formation of tetrathiomolybdate (reaction 3 - 4) were calculated by use of MinQL+ (equilibrium calculation software, [73] from Mo and sulfide data measured by colorimetry constants from Erickson and Helz [74] corrected and rearranged according to Lake Pavin ionic strength were used for calculation.

$$
\log \mathrm{K}_{0-1}=12.38 \pm 0.03 ; \log \mathrm{K}_{1-2}=24.5 \pm 0.12 ; \log \mathrm{K}_{2-3}=36.53 \pm 0.13 ; \log \mathrm{K}_{3-4}=48.59 \pm 0.28
$$

The equilibrium model output is shown on Figure 12.

Contrary to the Black Sea [74], there is no total transformation to tetrathiomolybdate due to a lack of free sulfide. At the most, dissolved molybdenum in the monimolimnion is roughly half under the form of molybdate and half under the form of monothiomolybdate, the less reactive form of thiomolybdates. Vorlicek [4] suggest that thiomolybdates adsorbed onto iron sulfide and onto pyrite form Fe-Mo-S cluster stabilized by the reduction of $\mathrm{Mo}(\mathrm{VI})$ to $\mathrm{Mo}\left(\mathrm{V}\right.$ or IV) in presence of $\mathrm{H}_{2} \mathrm{~S}$ and $\mathrm{S}(0)$-donors. More recently Helz et al. [42] even suggest a mineral's formula that applies in sulfidic anoxic marine environment $\left(\mathrm{Fe}_{5} \mathrm{Mo}_{3} \mathrm{~S}_{14}\right)$ however the same model does not fit completely Lake Pavin Mo data. Until now thiomolybdates cannot be measured in the environment directly but Lake Pavin mesolimnion seems to have all necessary conditions to fit the more consensual removal pathway of dissolved molybdenum in sulfidic environment: thermodynamically possible thiomolybdates formation, adsorption onto and co-precipitation with iron sulfide.

The subsistence of stable molybdate in the monimolimnion and its association with natural organic matter [38] would most probably explain the incomplete removal of dissolved molybdenum for the anoxic compartments. Viollier [61] showed that iron oxyhydroxides formed in the mixolimnion of Lake Pavin mainly dissolve at the sediment-water interface. The reductive dissolution of these carrier phases would release molybdenum and contribute to the deep enhancement of its concentration. This statement is highly in accordance with FeS profile previously given in papers [68] [69].

\section{Conclusion}

The seasonal study of dissolved molybdenum allowed the observation of transient phenomenon likely explained by microalgae uptake in the epilimnion. Oscillating feature of dissolved molybdenum depletion at intermediate depth is explained by adsorption onto iron and manganese oxyhydroxides and/or by the injection of a sublacu- 


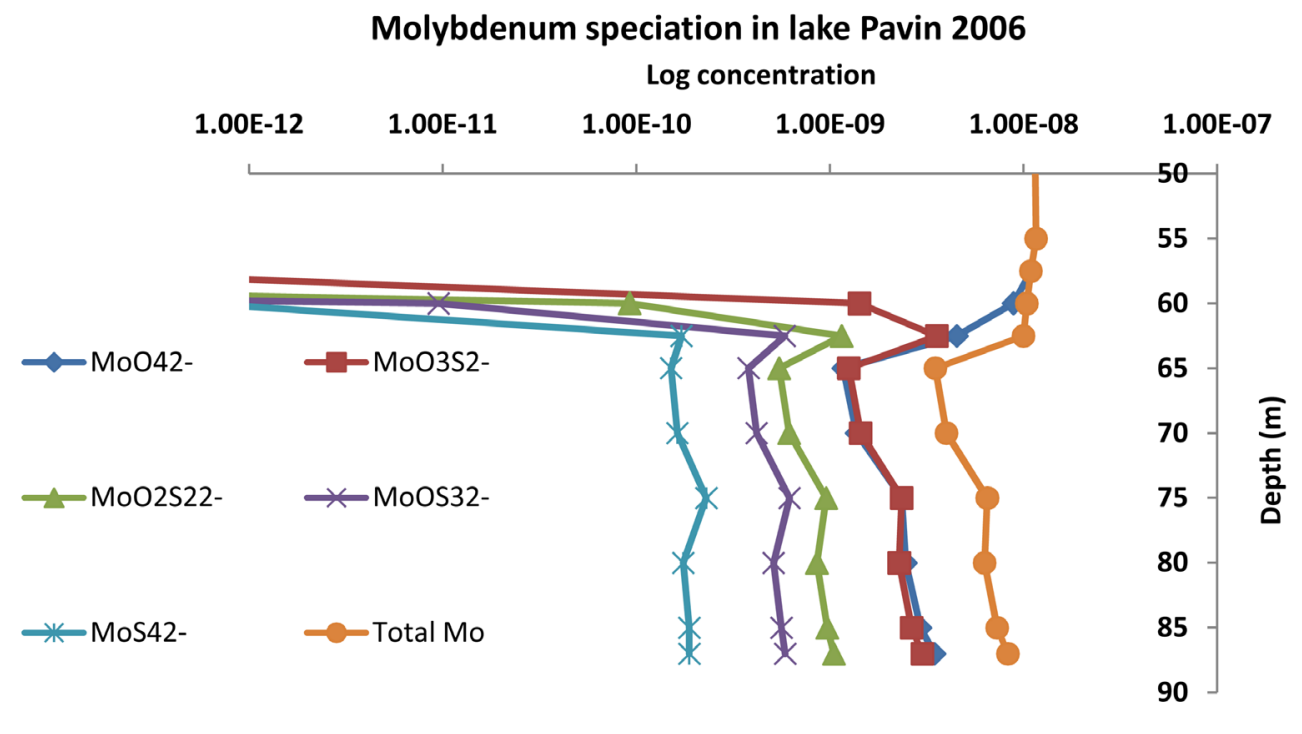

Figure 12. Dissolved molybdenum speciation in Lake Pavin.

strine input containing lower molybdenum concentration. The depletion zone, however, follow more or less the oxycline rise up. This characteristic would argue for the adsorption pathway. In this work, it has also been shown that strong removal in the sulfidic zone is permanent and does not respond significantly to seasonal changes. The most favorable removal pathway involves thiomolybdates formation and reaction with authigenic iron sulfides. At what extent, natural organic matter is involved in long term removal or burial of molybdenum, is still in debate.

\section{Acknowledgements}

J.-C. Romagoux was of great help to obtain "good shape" Aulacoseira italica and to maintain them in a "useful shape” for our experiment. University of Clermont-Ferrand helped with the field logistics. S. Lafortune was very helping for field work. M. Pèpe has helped with the ICP-MS work. This work was partially funded by ANR with the METANOX project.

\section{References}

[1] Stiefel, E.-I. (1997) Chemical Keys to Molybdenum Enzymes. Journal of the Chemical Society, No. 21, $3915-3923$.

[2] Williams, R.-J.P. and Frausto da Silva, J.-J.R. (2002) The Involvement of Molybdenum in Life. Biochemical and Biophysical Research Communications, 292, 293-299. http://dx.doi.org/10.1006/bbrc.2002.6518

[3] Zheng, Y., Anderson, R.-F., van Geen, A. and Kuwabara, J. (2000) Authigenic Molybdenum Formation in Marine Sediments: A Link to Pore Water Sulfide in the Santa Barbara Basin. Geochimica et Cosmochimica Acta, 64, 4165-4178. http://dx.doi.org/10.1016/S0016-7037(00)00495-6

[4] Vorlicek, T.-P., Kahn, M.-D., Kasuya, Y. and Helz, G.-R. (2004) Capture of Molybdenum in Pyrite-Forming Sediments: Role of Ligand-Induced Reduction by Polysulfides. Geochimica et Cosmochimica Acta, 68, 547-556. http://dx.doi.org/10.1016/S0016-7037(03)00444-7

[5] Ciglenečki, I., Pichler, S., Prohić, E. and Ćosović, B. (2006) Distribution of Redox-Sensitive Elements in Bottom Waters, Porewaters and Sediments of Rogoznica Lake (Croatia) in both Oxic and Anoxic Conditions. Water, Air, \& Soil Pollution: Focus, 6, 537-545. http://dx.doi.org/10.1007/s11267-006-9037-2

[6] Poulson, R., Siebert, C., McManus, J. and Berelson, W.M. (2006) Antigenic Molybdenum Isotope Signatures in Marine Sediments. Geology, 34, 56-59. http://dx.doi.org/10.1130/G22485.1

[7] Tribovillard, N., Lyons, T., Riboulleau, A. and Bout-Roumazeilles, V. (2008) A Possible Capture of Molybdenum during Early Diagenesis of Dysoxic Sediments. Bulletin de la Société Géologique de France, 179, 3-12. http://dx.doi.org/10.2113/gssgfbull.179.1.3

[8] Magyar, B., Moor, H.C. and Sigg, L. (1993) Vertical Distribution and Transport of Molybdenum in a Lake with a Seasonally Anoxic Hypolimnion. Limnology and Oceanography, 38, 521-531. http://dx.doi.org/10.4319/lo.1993.38.3.0521

[9] Howarth, R.W. and Cole, J.J. (1985) Molybdenum Availability, Nitrogen Limitation, and Phytoplankton Growth in 
Natural Waters. Science, 229, 653-655. http://dx.doi.org/10.1126/science.229.4714.653

[10] Howarth, R.W., Marino, R., Lane, J. and Cole, D.R. (1988) Nitrogen Fixation in Freshwater, Estuarine and Marine Ecosystems. 1. Rates and Importance. Limnology and Oceanography, 33, 669-687. http://dx.doi.org/10.4319/lo.1988.33.4_part_2.0669

[11] Howarth, R.W. (1988) Nutrient Limitation of Net Primary Production in Marine Ecosystems. Annual Review of Ecology and Systematics, 19, 89-110. http://dx.doi.org/10.1146/annurev.es.19.110188.000513

[12] Marino, R., Howarth, R.-W., Shamess, J. and Prepas, E. (1990) Molybdenum and Sulfate as Controls on the Abundance of Nitrogen-Fixing Cyanobacteria in Saline Lakes in Alberta. Limnology and Oceanography, 35, 245-259.

[13] Paulsen, D.-M., Paerl, H.-W. and Bishop, P.-E. (1991) Evidence That Molybdenum Dependent Nitrogen Fixation Is Not Limited by High Concentrations of Sulfate in Marine Environments. Limnology and Oceanography, 36, 13251334.

[14] Cole, J.-J., Lane, J., Marino, R. and Howarth, R.W. (1993) Molybdenum Assimilation by Cyanobacteria and Phytoplankton in Freshwater and Salt Water. Limnology and Oceanography, 38, 25-35. http://dx.doi.org/10.4319/lo.1993.38.1.0025

[15] Tuit, C., Waterbury, J. and Ravizza, G. (2004) Diel Variation of Molybdenum and Iron in Marine Diazotrophic Cyanobacteria. Limnology and Oceanography, 49, 978-990.

[16] Morris, A.W. (1975) Dissolved Molybdenum and Vanadium in the Northeast Atlantic Ocean, Deep-Sea. Deep-Sea Research and Oceanographic Abstracts, 22, 49-54.

[17] Collier, R.-W. (1985) Molybdenum in the Northeast Pacific. Ocean. Limnology and Oceanography, 30, $1351-1354$. http://dx.doi.org/10.4319/lo.1985.30.6.1351

[18] Brewer, P.G. (1975) Minor Elements in Seawater. In: Riley, J.P., Ed., Chemical Oceanography, Academic Press, Waltham, 415-496.

[19] Calvert and Pedersen (1993) Geochemistry of Recent Oxic and Anoxic Sediments: Implications for the Geological Record. Marine Geology, 113, 67-88. http://dx.doi.org/10.1016/0025-3227(93)90150-T

[20] Emerson, S.-R. and Huested, S.-S. (1991) Ocean Anoxia and the Concentrations of Molybdenum and Vanadium in Seawater. Marine Chemistry, 34, 177-196. http://dx.doi.org/10.1016/0304-4203(91)90002-E

[21] Colodner, D., Edmond, J. and Boyle, E. (1995) Rhenium in the Black Sea: Comparison with Molybdenum and Uranium. Earth Planetary Sciences Letters, 131, 1-15. http://dx.doi.org/10.1016/0012-821X(95)00010-A

[22] Bertine, K.K. and Turekian, K.K. (1973) Molybdenum in Marine Sediments. Geochimica et Cosmochimica Acta, 37, 1415-1434. http://dx.doi.org/10.1016/0016-7037(73)90080-X

[23] Brumsack, H.-J. and Gieskes, J. (1983) Interstitial Water Trace-Metal Chemistry of Laminated Sediments form the Gulf of California, Mexico. Marine Chemistry, 14, 89-106. http://dx.doi.org/10.1016/0304-4203(83)90072-5

[24] Brumsack, H.-J. (1986) The Inorganic Geochemistry of Cretaceous Black Shales (DSDP Leg 41) in Comparison to Modern Upwelling Sediments from the Gulf of California. In: Summerhayes, C.P. and Shackleton, N.J., Eds., North Atlantic Palaeoceanography, Special Publications, Geological Society London, 21, 447-462.

[25] Piper, D.-Z. and Isaacs, C.-M. (1995) Minor Elements in Quaternary Sediment from the Sea of Japan: A Record of Surface-Water Productivity and Intermediate-Water Redox Conditions. Geology. Society. America Bulletin, 107, 54-67.

[26] Crusius, S., Calvert, T., Pedersen, T. and Sage, D. (1996) Rhenium and Molybdenum Enrichments in Sediments as Indicators of Oxic, Suboxic, and Sulfidic Conditions of Deposition. Earth Planetary Sciences Letters, 145, 65-78. http://dx.doi.org/10.1016/S0012-821X(96)00204-X

[27] Helz, G.-R., Miller, C.-V., Mosselmans, J.M.W., Patrick, R.-A.D., Garner, C.-D. and Vaughan, D.-J. (1996) Mechanisms of Molybdenum Removal from the Sea and Its Concentration in Black Shale: EXAFS Evidence. Geochimica et Cosmochimica Acta, 60, 3631-3642. http://dx.doi.org/10.1016/0016-7037(96)00195-0

[28] Nameroff, T. (1996) The Geochemistry of Redox-Sensitive Metals in Sediments of the Oxygen Minimum off Mexico. Ph.D. Thesis, University of Washington, Seattle.

[29] Morford, J.-L. (1999) The Geochemistry of Redox-Sensitive Trace Elements. Ph.D. Thesis, University of Washington, Seattle.

[30] Morford, J. and Emerson, S. (1999) The Geochemistry of Redox Sensitive Trace Metals in Sediments. Geochimica et Cosmochimica Acta, 63, 1735-1750. http://dx.doi.org/10.1016/S0016-7037(99)00126-X

[31] Siebert, C., Nagler, T.F., von Blanckenburg, F. and Kramers, J.D. (2003) Molybdenum Isotope Records as a Potential New Proxy for Paleoceanography. Earth and Planetary Science Letters, 211, 159-171. http://dx.doi.org/10.1016/S0012-821X(03)00189-4

[32] Anbar, A.D. (2004) Molybdenum Stable Isotopes: Observations, Interpretations and Directions. In: Geochemistry of 
Non-Traditionnal Stable Isotopes, Vol. 55, Mineralogical Society of America and Geochemical Society, Washington, 429-454.

[33] Kolodkin-Gal, I., Hazan, R., Gaathon, A., Carmeli, S. and Engelberg-Kulka, H. (2007) A Linear Pentapeptide Is a QuorumSensing Factor Required for mazEF-Mediated Cell Death in Escherichia coli. Science, 318, 652-655. http://dx.doi.org/10.1126/science.1147248

[34] Kroneck, P.M.H. and Abt, D.J. (2002) Molybdenum in Nitrate Reductase and Nitrate Oxidoreductase. In: Sigel, H. and Sigel, A., Eds., Metal Ions in Biological Systems, Marcel Dekker Inc., New York, 369-403.

[35] Barling, J. and Anbar, A.D. (2004) Molybdenum Isotope Fractionation during Adsorption by Manganese Oxides. Earth and Planetary Sciences Letters, 217, 315-329. http://dx.doi.org/10.1016/S0012-821X(03)00608-3

[36] Adelson, J.M., Helz, G.R. and Miller, C.V. (2001) Reconstructing the Rise of Recent Coastal Anoxia, Molybdenum in Chesapeake Bay Sediments. Geochimica et Cosmochimica Acta, 65, 237-252. http://dx.doi.org/10.1016/S0016-7037(00)00539-1

[37] Elbaz-Poulichet, F., Seidel, J.L., Jézéquel, D., Metzger, E., Prévot, F., Simonucci, C., Sarazin, G., Viollier, E., Etcheber, H., Jouanneau, J.M., Weber, O. and Radakovitch, O. (2004) Sedimentary Record of Redox-Sensitive Elements (U, Mn, Mo) in a Transitory Anoxic Basin (the Thau lagoon, France). Marine Chemistry, 95, 271-281. http://dx.doi.org/10.1016/j.marchem.2004.10.001

[38] Albéric, P., Viollier, E., Jezequel, D., Grosbois, C. and Michard, G. (2000) Interactions between Trace Elements and Dissolved Organic Matter in the Stagnant Anoxic Deep Layer of a Meromictic Lake. Limnology and Oceanography, 45, 1088-1096. http://dx.doi.org/10.4319/lo.2000.45.5.1088

[39] Kawakubo, S., Hashi, S. and Iwatsuki, S. (2001) Physicochemical Speciation of Molybdenum in Rain Water. Water Research, 35, 2489-2495. http://dx.doi.org/10.1016/S0043-1354(00)00520-0

[40] Korolev, D.F. (1958) The Role of Iron Sulfides in the Accumulation of Molybdenum in Sedimentary Rocks of the Reduced Zone. Geochemistry, 4, 452-463.

[41] Tribovillard, N., Riboulleau, A., Lyons, T. and Baudin, F. (2004) Enhanced Trapping of Molybdenum by Sulfurized Marine Organic Matter of Marine Origin in Mesozoic Limestones and Shales. Chemical Geology, 213, 385-401. http://dx.doi.org/10.1016/j.chemgeo.2004.08.011

[42] Helz, G.R., Bura-Nakic, E., Mikac, N. and Ciglenecki, I. (2011) New Model for Molybdenum Behavior in Euxinic Waters. Chemical Geology, 284, 323-332. http://dx.doi.org/10.1016/j.chemgeo.2011.03.012

[43] Olivier, L. (1952) Sur la présence en été, dans le Lac Pavin, d’une couche dépourvue d'oxygène, vers 70 m de profondeur. Comptes Rendus de l'Académie des Sciences Paris, 234, 743-745.

[44] Alvenerie, J., Dégot, B., Lévèque, P. and Vigneaux, M. (1966) Activité en tritium et caractéristiques chimiques des eaux du Lac Pavin. Comptes Rendus de l'Académie des Sciences, 262, 846-849.

[45] Omaly, N. (1968) Le lac Pavin: Historique et Hydrobiologie. Revue des Sciences Naturelles d'Auvergne, 34, 7-30.

[46] Pelletier, J.P. (1968) Un lac méromictique, le Pavin (Auvergne)/A Meromictic Lake Lake Pavin (Auvergne). Annales de la Station Biologique de Besse-en-Chandesse, (3), 147-170.

[47] Meybeck, M., Martin, J.M. and Olive, P. (1975) Géochimie des eaux et des sédiments de quelques lacs volcaniques du Massif Central français. Verhandlungen Internationalen Vereinigung Limnologie, 19, 1150-1164.

[48] Devaux, J., Lair, N. and Amblard, C. (1983) Un écosystème lacustre profond: Le Lac Pavin. In: Masson, Ed., Problèmes d'Écologie: Écosystèmes Limniques, M. Lamotte et F. Bourlière, 1-49.

[49] Amblard, C. and Restituito, F. (1983) Observations complémentaires en faveur de l'origine biogénique de la couche à hydrogène sulfuré d'un Lac de moyenne montagne (Lac Pavin, France). Comptes Rendus de l'Académie des Sciences Paris, 296, 1787-1790.

[50] Restituito, F.V. (1984) Study of a Layer Containing Hydrogen Sulfide in a Meromictic Lake Pavin, France. Hydrobiologia, 109, 235-242.

[51] Restituito, F.V. (1987) Consequences of Redox Conditions on the Distribution of Cations in a Meromictic Oligotrophic Lake. Hydrobiologia, 144, 63-75.

[52] Martin, J.M. (1985) The Pavin Crater Lake. In: Stumm, W., Ed., Chemical Processes in Lakes, John Wiley \& Sons Publishing, London, 169-188.

[53] Martin, J.M., Meybeck, M., Nijampurka, V.N. and Somayajulu, B.L.K. (1992) ${ }^{210} \mathrm{~Pb}$, ${ }^{226}$ Ra and ${ }^{32} \mathrm{Si}$ in Lac Pavin (Massif Central, France). Chemical Geology, 94, 173-181. http://dx.doi.org/10.1016/S0009-2541(10)80002-6

[54] Camus, G., Michard, G., Olive, P., Boivin, P., Desgranges, P., Jézéquel, D., Meybeck, M., Peyrus, J.C., Vinson, J.M., Viollier, E. and Kornprosbt, J. (1993) Risques d'éruption gazeuse carbonique en Auvergne. Bulletin Société Géologique de France, 164, 767-781. 
[55] Cossa, D., Mason, R.P. and Fitzgerald, W.F. (1994) Chemical Speciation of Mercury in a Meromictic Lake. In: Watras, C.J., Ed., Mercury Pollution, Lewis Publishers-CRC Press, Boca Raton, 57-67. .

[56] Michard, G., Viollier, E., Jézéquel, D. and Sarazin, G. (1994) Geochemical Study of a Crater Lake: Lac Pavin, FranceIdentification, Location and Quantification of the Chemical Reactions in the Lake. Chemical Geology, 115, 103-115. http://dx.doi.org/10.1016/0009-2541(94)90147-3

[57] Michard, G., Jézéquel, D. and Viollier, E. (2003) Vitesses des réactions de dissolution et précipitation au voisinage de l'interface oxydo-réducteur dans un lac méromictique: Le Lac Pavin (Puy-de-Dôme, France). Revue des Sciences de l'Eau, 16, 199-218. http://dx.doi.org/10.7202/705504ar

[58] Schmid, M. (1997) Physikalische and Chemische Prozesse in Lacbbv. Physikalische und chemische prozesse im lac Pavin: ursachen und folgen der satbilen schichtung eines vulkanishen kratersees. Diploma Thesis ETH Zürich, Suisse, $93 \mathrm{p}$.

[59] Viollier, E. (1995) Géochimie des éléments traces en milieu lacustre. Ph.D Thesis. Université Paris, Paris, 7.

[60] Viollier, E., Alberic, P., Jézéquel, D., Michard, G., Pepe, M. and Sarazin, G. (1995) Geochemical Study of a Crater Lake (Lake Pavin, France): Trace Element Behaviour in the Monimolimnion. Chemical Geology, 125, 61-72. http://dx.doi.org/10.1016/0009-2541(95)00059-U

[61] Viollier, E., Michard, G., Jézéquel, D., Pepe, M. and Sarazin, G. (1997) Geochemical Study of a Crater Lake: Lake Pavin, Puy de Dôme, France. Constraints Afforded by the Particulate Matter Distribution in the Element Cycling within the Lake. Chemical Geology, 142, 225-241. http://dx.doi.org/10.1016/S0009-2541(97)00093-4

[62] Aeschbach-Hertig, W., Hofer, M., Kipfer, R., Imboden, D.M. and Wieler, R. (1999) Accumulation of Mantle Gases in a Permanently Stratified Volcanic Lake (Lac Pavin, France). Geochimica et Cosmochimica Acta, 63, 3357-3372. http://dx.doi.org/10.1016/S0016-7037(99)00257-4

[63] Aeschbach-Hertig, W., Hofer, M., Schmid, M., Kipper, R. and Imboden, D.M. (2002) The Physical Structure and Dynamics of a Deep, Meromictic Crater Lake (Lac Pavin, France). Hydrobiologia, 487, 111-136. http://dx.doi.org/10.1023/A:1022942226198

[64] Olive, P. and Boulègue, J. (2004) Etude biogéochimique d’un lac méromictique: Le Lac Pavin, France. Géomorphologie: Relief, Processus, Environnement, 10, 305-316. http://dx.doi.org/10.3406/morfo.2004.1226

[65] Lehours, A.C., Bardot, C., Thenot, A., Debroas, D. and Fonty, G. (2005) Anaerobic Microbial Communities in Lake Pavin, a Unique Meromictic Lake in France. Applied and Environmental Microbiology, 71, 7389-7400. http://dx.doi.org/10.1128/AEM.71.11.7389-7400.2005

[66] Lehours, A.C., Evans, P., Bardot, C., Joblin, K. and Fonty, G. (2007) Phylogenetic Diversity of Archae and Bacteria in the Anoxic Zone of a Meromictic Lake (Lake Pavin, France). Applied and Environmental Microbiology, 73, 2016-2019. http://dx.doi.org/10.1128/AEM.01490-06

[67] Schettler, G., Schwab, M.J. and Stebich, M. (2007) A 700 Years Record of Climate Change Based on Geochemical and Palynological Data from Varved Sediments (Lac Pavin, French Massif Central). Chemical Geology, 240, 11-35. http://dx.doi.org/10.1016/j.chemgeo.2007.01.003

[68] Bura-Nakić, E., Viollier, E., Jézéquel, D., Thiam, A. and Ciglenečki, I. (2009) Reduced Sulfur and Iron Species in Anoxic Water Column of Meromictic Crater Lake Pavin (Massif Central, France). Chemical Geology, 266, 320-326. http://dx.doi.org/10.1016/j.chemgeo.2009.06.020

[69] Bura-Nakić, E., Viollier, E. and Ciglenečki, I. (2013) Electrochemical and Colorimetric Measurements Show the Dominant Role of FeS in a Permanently Anoxic Lake. Environmental Sciences \& Technology, 47, 741-749.

[70] Lopes, F., Viollier, E., Thiam, A., Michard, G., Abril, G., Groleau, A., Prévot, F., Carrias, J.F., Albéric, P. and Jézéquel, D. (2011) Biogeochemical Modelling of Anaerobic vs. Aerobic Methane Oxidation in a Meromictic Crater Lake (Lake Pavin, France). Applied Geochemistry, 26, 1919-1932. http://dx.doi.org/10.1016/j.apgeochem.2011.06.021

[71] Assayag, N., Jézéquel, D., Ader, M., Viollier, E., Michard, G., Prévot, F. and Agrinier, P. (2008) Hydrological Budget, Carbon Sources and Biogeochemical Processes in Lac Pavin (France): Constraints from $\delta^{18} \mathrm{O}$ of Water and $\delta^{13} \mathrm{C}$ of Dissolved Inorganic Carbon. Applied Geochemistry, 23, 2800-2816. http://dx.doi.org/10.1016/j.apgeochem.2008.04.015

[72] Mignot, J.P. and Brugerolle, G. (1982) Scale Formation in Chrysomonad Flagellates. Journal of Ultrastructure Research, 81, 13-26. http://dx.doi.org/10.1016/S0022-5320(82)90037-5

[73] Schecher, W.-D. and McAvoy, D.C. (1992) Equilibrium Calculation Software.

[74] Erickson, B.E. and Helz, G.R. (2000) Molybdenum (VI) Speciation in Sulfidic Waters: Stability and Lability of Thiomolybdates. Geochimica et Cosmochimica Acta, 64, 1149-1158. 